\title{
Fatal violence - from trauma to offence: A case study in forensic psychotherapy and trauma therapy with a migrant patient
}

\author{
TILMAN KLUTTIG, MICHAEL ODENWALD \& WERNER HARTMANN
}

\begin{abstract}
That persons who are objects of violence and traumatisation become offenders themselves is a typical feature of ill-fated cycles of violence in countries torn by fierce political, ethnic, and religious conflicts. Some refugees and migrants with this background present a challenge to forensic psychotherapy when they continue such patterns of physical force and criminal behaviour in a host country like Germany, and are found to be either not responsible or of diminished responsibility for their criminal acts by reason of mental disorders or addictions. Their offences create a critical legal situation for them, since they are threatened with deportation. At the same time, their clinical condition is critical, for they were possibly subjected to traumatic experiences by authorities in their past; their cooperation in the treatment can seriously affect their legal status. Finding a way out of these complications has to take these special factors into account. Our paper focuses on the case study of a refugee from North Africa, illustrating a model of cooperation in forensic inpatient treatment, special trauma therapy (narrative exposure therapy), and expert testimony.
\end{abstract}

Key words: Forensic psychotherapy, post-traumatic stress disorder, refugees, immigrants, narrative exposure therapy

The treatment of migrants having uncertain residential status typically takes place in a difficult and complex field of conflicts determined by cultural differences, legal questions pertaining to residence, and social pressures. It is often hard to maintain the integrity of the therapeutic situation in such cases. Even more difficult is the treatment of migrants who have committed a serious offence and for whom, on the basis of the legal requirements, the court orders incarceration and treatment in a forensic psychiatric facility. (This is, inter alia, possible under German criminal law if a mental disorder is present that leads to diminished responsibility or to nonresponsibility, or if the offence is related to a serious addictive illness, which, it must be assumed, will lead to further criminal acts if the offender is not treated.)

On the one hand, the case described here seems to us paradigmatic of the difficulties of such therapies; on the other hand, it makes clear the possible interactions between a personally violent life and the possible criminal development of a migrant. It also shows how the narrowness of (German) regulations on foreigners can adversely affect the positive results of treatment and endanger long-term integration. The patient presented here is not allowed to work, and the authorities have placed him in a living facility for applicants for political asylum and "tolerated" foreigners in which the living conditions are shaped by poverty, violence, and drug abuse. The situation seems absurd. After a quite successful therapy in forensic psychiatry, the authorities, at the behest of the state, release the patient into a social space replete with risks of recidivism and which contradicts every prognostic recommendation. Nonetheless, we share our patient's opinion that the therapy was meaningful and valuable even if he must reckon with being deported at some point in the future.

Examples from Third World and rapidly developing nations, as well as from Europe (e.g. Northern Ireland), show how future offenders in civil wars are recruited from the victims and thus how a continuing dynamic of flight, expulsion, and violence arises, which the perpetrators justify by the fact that they were victims themselves. Such a dynamic also becomes evident in the biography of our patient. $\mathrm{He}$ hails from Algeria, and he and we believed at the start

Correspondence: Tilman Klutrig, clinical psychologist and psychotherapist, senior clinical psychologist, Zentrum für Psychiatrie Reichenau, Department of Forensic Psychiatry and Psychotherapy, Feursteinstrasse 55, D-78479 Reichenau, Germany. E-mail: t.kluttig@zfp-reichenau.de 
that he had come within a hair's breadth of pursuing the career of an Islamist terrorist. Like many others at the beginning of the $1990 \mathrm{~s}$, he was embroiled in the increasingly escalating and violent conflicts between the Algerian government and the Islamic Salvation Front (the Front Islamique du Salut, or FIS).

\section{Migrants in German forensic psychiatry}

The proportion of migrants in forensic psychiatry in Germany has continued to increase in recent years (Hoffmann, Kluttig, \& Ross, in press). Turkish, Polish, and Italian citizens, along with citizens of the successor states to former Yugoslavia and the Warsaw Pact countries, represent the majority of the foreign citizens in forensic psychiatry. Studies show overall that the proportion of migrants - foreigners and resettled Germans - in forensic psychiatry in Germany is significantly higher than in general psychiatry, clearly higher than their proportion in the population as a whole and lower than in the penal system (Hoffmann et al., in press).

A 2004 investigation in the Bavarian forensic clinics revealed a foreigner share of about $15 \%$ (Hausner et al., 2006, p. 70). Likewise in 2004, a study carried out on a specific date in 12 psychiatricpsychotherapeutic and psychosomatic clinics demonstrated that the largest share $(27.2 \%)$ of the patients with a migration background were being treated in the forensic divisions (Koch, Hartkamp, \& Schouler-Ocak, 2007). Hoffmann (2006), in a study in the three forensic psychiatric units in Baden over the period 1990-2000, showed that the proportion of foreigners among the forensic patients admitted (17.1\%) was significantly above the proportion of foreigners in the general population $(12.2 \%$ in Baden-Württemberg in 2000), but still clearly below the proportion among prisoners in the penal system (26.9\% in Baden-Württemberg in these 10 years). Similarly, as in the police criminal statistics, foreigners interned under special measures committed more offences against life and limb as well as drug offences, but at the same time fewer sexual offences against children, thefts, and frauds, and less arson (Hoffmann et al., in press).

We have already touched upon the factor of legal conditions. Because these always play an essential role in the treatment of refugees and migrants, it is necessary to explain the situation of the patient being described here. He was born in Algeria in 1965. In 1991, he joined the FIS. In 1992, he was arrested, tortured, and taken to a prison in the Sahara. There he fell mentally ill. After 5 months, he came into a psychiatric clinic, from which he succeeded in escaping. With the help of the FIS and equipped with false documents, he boarded a ship and reached
Marseilles, where he went into hiding and then moved on to Germany. Here, he submitted an application for political asylum, which was rejected by the Federal Office for the Recognition of Foreign Refugees (BAFL).

But, at least in 1994, it was acknowledged that deporting him would put him in danger of being tortured anew. Thus, our patient acquired the status of a so-called "tolerated" foreigner. Persons with this status must apply for permanent residence at the end of 2 years. Due to his drug dependency, which had developed in the meantime, he failed to meet the deadline. Moreover, he committed criminal offences, dealt in drugs, and in 1997 was sentenced for the first time to a longer term of punishment. After completing a part of the sentence, he was given a first drug therapy, which, however, had no lasting success. Back in the living quarters for foreigners, he consumed drugs anew, and in 2001 was again given a long sentence and interned pursuant to the criminal code in a corrective institution. After finishing a part of the term in remand and prison, he was transferred to our division.

In the meantime the BAFL, with a view to his offences, had cancelled his "tolerated" status and issued a legally binding expulsion order, because in 2000 an amnesty for FIS activists who had not committed severe offences (e.g. murder, rape or bomb attacks) was proclaimed by the Algerian government. The patient submitted an appeal, which was declined in the first instance. In a further decision, the high court of administration put the "tolerated" status back in force. After being released from confinement pursuant to the special measure, this meant that he had to keep to the conditions imposed by the government office responsible for him as a foreigner, that he was granted no work permit, and at first had to live in a collective facility. For his future, the "toleration" continues to mean an uncertain legal status.

\section{A fallen prince - the case study}

Whenever possible, we ask patients in our division at the beginning of treatment to paint a so-called life panorama. Structure, form, and working tools are left up to them. This patient drew quite a few key pictures with a pencil, and at times added to them with a red felt marker. Such pictures are often helpful first steps into the patient's biography and can also be used by patients when introducing themselves in the group therapy. With this patient, they also offered an access to biographical data that he had previously never revealed to the authorities or other clinics.

Mr A was born in 1965 in Algeria as one of his parents' 11 children; he has five older sisters and 
one older brother as well as three younger sisters and one younger brother. He reports that in childhood he was his parents' favourite - on the one hand as a son, on the other because he was, in contrast to his older brother, described as hyperactive, a rather quiet and satisfied child. A particularly close relation existed between him and his mother. His special role becomes clear in several pictures based on his childhood years in which he always turns up alone - his siblings do not appear.

In 1973 the family moved to Paris, where Mr A also went to school. $\mathrm{He}$ and his mother had a common dream that later on, given his talent and energy, he could become a doctor and take care of her when she got old. In his life panorama he paints himself in a physician's white coat and appends his name plus a doctor title. After finishing school, he worked in an uncle's small textile business. Proudly, he relates today how he finished his apprenticeship there at the age of 18 and how this was observed with a big family celebration. He was the middle point of the family, as he tells it, and especially loved by his mother through his achievements in work and sports the prince of the family, on whom all hopes were pinned.

He had always liked to help his mother with cooking and baking, which did not necessarily correspond to the stereotype of manliness in his culture. When he took up further occupational training as a confectioner, his father put up resistance at first. The latter held this work to be unmanly and, even when the son helped with the housekeeping, was afraid the boy could be homosexual. He convinced his mother to put in a word for him, and in the end he was able to start the training all the same. After his first year, his parents returned to Algeria, where his father opened a restaurant. $\mathrm{He}$ stayed in Paris, living with an aunt and ending his training there.

It was there that he met his first girlfriend. When she went back to Algeria with her family and his father offered him a job in the restaurant; therefore, he too left France and returned to Algeria in 1990. He was engaged to be married to his girlfriend, but in 1990 she was killed together with her family in an automobile accident. He relates that he withdrew into himself for one to two months after this event, "sick in the head," until with his parents" help he could come to terms with this loss to some degree.

Shortly after this traumatic incident, the family was surprised suddenly in the middle of the night by a task force of the Algerian police. The patient's dog barked, shots were fired, and about 20 men burst into the house. $\mathrm{Mr} \mathrm{A}$, his mother, and his siblings were threatened with drawn arms; his father was overpowered and beaten in the sight of the family, thrown onto the floor, tied up, and finally carried off. $\mathrm{Mr} \mathrm{A}$ found his dog shot dead. In a report on his experiences at the time, he said:

The whole mourning over the death of my girlfriend came back. ... I had the feeling that I couldn't go on living. ... I lay there and thought, now I'm finished with life. ... I had lots of anger in me too. Anger at the shitty law in our country. I felt this anger everywhere. It felt like my whole body was screaming, about to explode to let the anger out.

The family left behind was, so he said, frozen by shock. Only after some effort, with the help of his uncle, were they able to learn what the father was accused of and where he had been taken. The charge was that, within the framework of a volunteer activity with an aid organisation, he had bought arms for terrorists. He was convicted and condemned to a term in prison.

Mr A reports that although he had previously followed the political conflicts in Algeria, he had felt quite distanced from them -"It has nothing to do with me." But now he had developed feelings of revenge and turned to acquaintances in the FIS. These took him in and gave him a task as a marshal at demonstrations, warning him, however, not to take part in violent actions. In the meantime, the family had found out where the father was incarcerated; the mother and the elder brother visited him there.

A few months later, $\mathrm{Mr}$ A was deployed as a marshal at a demonstration during which serious clashes with the police occurred and the latter finally fired into the crowd, causing, according to him, some 18 deaths. He himself was in the midst of the action and afterwards visited the wounded in hospital as a representative of the FIS. The next step of his politicisation or radicalisation followed. With three friends, like himself raised and schooled in France, he decided to move to Algiers to fight against the government. The family, especially his mother, opposed this plan firmly, fearing that he could become embroiled in acts of violence there, and wanted to send him back to France instead. But he prevailed with the argument that he wished to go to Algiers to study the Koran.

In the capital, he and his friends found their way to higher officials of the FIS. At this time, 1992, Boudiaf, a founder of the National Liberation Front (Front pour la Libération National, or FLN), returned from his 27 years Moroccan exile as new Chairman of the High Council of State and seemed 
to many, for a short period, an alternative between the corrupt FLN regime and the FIS that was gaining more and more ground. Our patient too belonged to his supporters. In June 1992, Boudiaf was assassinated by one of his bodyguards.

At a mourning demonstration for Boudiaf, $\mathrm{Mr} \mathrm{A}$ witnessed again how the military and the police fired into the crowd - as well as that many demonstrators were armed and fired back. He believes that on that day over 200 persons were killed. Today he recalls:

When I think about it today I still must cry and I have a completely dry mouth. I can't swallow any more, and it's hard for me to breathe. My stomach hurts.... I have the experience again and again that my thoughts go away quite quickly when I'm really doing something else. It's as though they were drawn away. When I watch TV it happens sometimes very fast. My eyes keep watching, but my thoughts are gone. For example, they're with a man who's lying on the ground. I see him, too. I see a bloody head, but I don't know whether it's the one that was shot. ... It looks like a battlefield. Sometimes I see a man who was hit by a big shell..."

Afterwards he was very upset. He repeatedly took part in disturbances on the side of the FIS, putting together and throwing Molotov cocktails and incendiary bombs. He was finally summoned to an FIS meeting at which targeted armed operations were planned.

At this point, he discussed things with his friends, and it became clear to him that if he went to this meeting, he would become more and more embroiled. He returned instead to his home town and continued to work there with the unarmed section of the FIS. In the meantime, Algeria had become the site of an ever bloodier civil war: "It had become entirely normal that violence occurred constantly, and often people lay dead in the street." His mother urged him again and again to go to France; she feared that otherwise he could become involved in the struggles and turn into a terrorist. He himself shuttled between his home town and Algiers, while the FIS's fight against the government made up the real content of his life. On the one hand, he helped distribute political writings; on the other hand, he also participated in the violence. Several times, he experienced brutal fights and bomb explosions. Finally, he went home exhausted and burnt out: "I felt drugged." He hid from his mother what he had done in Algiers, since she would have disapproved of it.

A little later, in July 1992, he was arrested at home and taken away with a sack over his head in the boot of a vehicle. He was charged with having taken part in a bomb attack on a police station, and beyond that he was supposed to know the names and weapons caches of the armed branch of the FIS. He could not or would not answer the charge and was tortured on the "dance floor," as it was called: beaten, teeth knocked out, pushed under water in a bathtub, submitted to electric shock, and threatened with rape. In the process, one of his shinbones was broken.

In the drawing of his imprisonment, his hands are tied behind his back and he is surrounded by policemen with rifles. In the drawing of torture, he is bound with his hands behind his back, and his arms are pulled up onto a post with a rope. Many red spots symbolise the blood that flowed in the process. A basin with dirty water can be seen too; $\mathrm{Mr}$ A explains that his head was pushed into it. The last picture from the year 1992 shows him in a prison in the Sahara, behind bars with tears in his eyes, with in the background a camel and sand dunes.

Afterwards, he was treated in a military hospital and then brought to a military prison, also in the Sahara. It was here that he fell ill. "After two months a djinn took possession of me." Apparently, he had auditory and visual hallucinations, felt himself to be possessed and plagued by "demons," and stuck out in the group of prisoners that otherwise displayed solidarity and mutual helpfulness through his paranoid ideas on relationships and unmotivated aggressions. With support from acquaintances of his father, he was transferred for assessment of his condition to a psychiatric clinic. With the help of the FIS, he was able to escape from there; for several months, he was kept in hiding until he had recovered. In this period, it was also possible for the first time for him to make contact with his family. With a false passport, he sailed to Marseilles on a freighter in 1993, went on to his aunt in Paris, destroyed the false passport, travelled to Germany, and applied for political asylum there. He chose Germany, so he recounted, because friends had warned him about the cooperation between the French and the Algerian authorities.

Here, he was placed in common living quarters; his application for asylum was rejected, but "toleration" was granted. This meant coming suddenly into a situation that was not only foreign to him and controlled by others but also ghetto-like and condemned him to inactivity. He repeatedly suffered on the one hand from psychogenic attacks, often when the police visited the premises; on the other hand, he often gave way to aggressive outbursts, mostly, when we look back on them today, in the context of flashbacks. He learned that his parents were incarcerated for a time - a package addressed to him was intercepted - and placed under pressure by being told that they would only be let out once he came back and surrendered to the police. 
In 1994, he came into contact for the first time with drugs - heroin and cocaine. He quickly began to consume daily and developed a severe dependency. $\mathrm{He}$ was arrested for the first time for alleged possession of drugs, but was released again after a short stay in remand. He made two massive suicide attempts in rapid succession and was in inpatient treatment on that account. From the clinic, he was accepted onto a methadone programme.

But he went on consuming and also dealing and was arrested again and sentenced to a prison term. In prison, he tried again several times to take his own life. Released early because of an opening for therapy, he then stabilised, at least on the surface, and started a relationship with a fellow patient, who became pregnant by him. After the birth of his daughter and his release from the therapeutic facility, he hoped to live with the woman, but this was impossible because of his status as a foreigner. He had to go back to the common living quarters, where after a short time he again consumed and dealt in drugs and undertook several further suicide attempts. Following another arrest and incarceration, he was finally sent to us for treatment.

\section{Integration of forensic psychotherapy and trauma therapy}

The patient came to us in a doubly exceptional situation. First, the facility that was officially responsible, $250 \mathrm{~km}$ distant, was overoccupied and could not admit him. In addition, the occupancy situation of our division was such that he had to be admitted immediately to the psychotherapy ward without the possibility of a previous interview.

Not only for this reason, we encountered $\mathrm{Mr} \mathrm{A}$ at first with a certain skepticism. For one thing, there was the two-year drug withdrawal treatment that seemed to have remained without lasting success. $\mathrm{He}$ denied the offences of drug dealing and physical assault listed in the sentences; his version was that he only had drugs in his possession for his own consumption and that he had acted in self-defence in threatening situations. Again and again, he assured us, like a profession of faith, that he did not want to take drugs in future. And his manner was pleasing, charming; he knew how to arouse sympathy in others. The question quickly arose as to what was true in all this and what was really wrong with him.

In the first phase of treatment - in which we are concerned with clarification of the therapeutic goals, diagnosis, and prognosis - patients have no exit privileges and are confined to the clinic building. It was in this context that $\mathrm{Mr}$ A's already mentioned life panorama was created. At the time, the panor- ama astonished us, for it communicated data not to be found in the available sentence documents and preliminary reports. The patient's files as a foreigner were administered separately from those of the courts. This split was confusing and made us wonder whether he and his statements were credible. At that time, the patient was concealing from us the burdens of his post-traumatic stress disorder (PTSD), which later became abundantly evident.

In the individual conversations, his assertions that drugs were bad, that he wanted to benefit from the therapy, and that he idealised us were predominant. This too made us suspicious that we were being manipulated by him; only later did we realise that the redundancy of his statements served precisely to avoid the negatively charged biographical facts, that is, the experiences - also as a perpetrator - in Algeria, the traumatisation through torture, and the shame over his drug addiction and his failure as a migrant due, in his opinion, to the drug dependency. Even after a long time in treatment, $\mathrm{Mr} \mathrm{A}$ hid both his criminal history and his drug addiction from his family in Algeria. It was impossible for him to confront his parents with his failure as a migrant; he felt that they would not be able to cope with it.

The way we experienced the patient changed by the end of this first phase of treatment. Now it was a matter of the first steps outside the ward, that is, the phase in which patients try to define their needs and to negotiate with us in trying to satisfy them. The heretofore so well-adapted and harmony-seeking patient now showed us another face. He became very demanding as regards both his material requirements and the concessions that he expected from the team. He wanted, so to speak, a reward for his good behaviour, and he reacted with tremendous wounded pride to postponements and refusals. $\mathrm{He}$ communicated this either through complaints and a depressive attitude, as though he felt discriminated against, or through severe temper tantrums. But at the same time, it was possible to speak with him about his biographical themes in individual and group therapy. And thus a transference scene rapidly took form in his behaviour that replicated the relations to his family members, especially to his mother. It was then that the treatment team gave him the nickname of "the little prince."

Mastering and clarifying these situations of apparent failure and his reactions to them made it increasingly possible for him to confront his criminal acts and drug dependency realistically; in a first step, he was able to connect his aggression with rage over his failure and to draw parallels to his inappropriate reactions in ward life. Moreover, we encouraged him to make use of his actual abilities. He worked in our laundry and later in our bakery, and proved to be a 
very good and capable employee in both - thereby repeating his positive narcissistic experience in France and Algeria. For this, he received corresponding appreciation from our side.

After a half-year of treatment, our skepticism toward him was definitely on the wane, and we began for the first time to perceive him as a sufferer. In his diffuse somatic symptoms and insomnia, we found a connection with everyday situations and strains, as well as with his unclear legal residence situation, which he now addressed in individual therapy.

Only now did we begin to consider and explore the question of a PTSD, looking back at the life panorama and the case history, and to understand his "good behaviour," as well as the ritual renouncing of drug consumption, as ways of avoiding this area. Incidentally, the patient remained abstinent throughout the whole therapy. He too now began cautiously to see connections between his vulnerability and touchiness and his life history. $\mathrm{He}$ was able to understand how he felt devalued - quickly and unjustifiably - by even trivial and unintentional insults. The next phase was a feeling of helplessness - the key igniting factor for either depressive withdrawal or temper tantrums. Contacts with the authorities and police, for example on leaves from the clinic, could set off attacks of panic. He reported often in the individual sessions and in the group about his fear of being deported to Algeria, but at the same time about his longing for his family. This longing involved ambivalence, since he had kept his drug addiction and criminal career secret from his relatives.

Mr A's psychic stability made it possible for him to get his bearings more and more outside the ward. He began a love relationship with a young woman and completed a practical training in a hospital kitchen, after which, and up to his release, he worked as a trainee in the kitchen of our clinic. Parallel to this development and his ever greater readiness to talk openly about his emotions, the tantrums diminished significantly. But at the same time, he reported more often about nightmares and flashback experiences. For example, he told about a dream in which he was smilingly given permission to enter Algeria, but when he walked into his family home he found blood everywhere and his parents slaughtered, decapitated. Or he had watched a film at the cinema, at first as a spectator. Although set in Algeria, German detectives were pursuing Algerian dealers. Suddenly he recognised himself in the film; he was drawn into the plot because a policeman was murdered. At the end, he had the feeling of becoming psychotic again and ran screaming through the streets. In this scene he woke up; completely bathed in sweat. Occasionally, he fell into depressive crises, so despondent and tearful that he could barely concentrate on his work.

For some time, we have worked with the psychology department at the University of Constance and their Outpatient Clinic for Refugees (cf. Garieballa et al., 2006; Kluttig, 2003; Schauer et al., 2002), and we pay particular attention to the links between stress disorders and their possible significance in the therapy and prognosis of forensic patients. In view of the ever more prevalent PTSD, we asked our colleagues at the university for support - at first for an assessment that might be helpful in making an appeal against a deportation order, later for a trauma therapy.

In the context of their activity over the years, these colleagues have developed a highly sensitive examination method that makes use of standardised clinical tests and the measurement of brain activity. The members of this research group have specialised, above all, in the framework of operations in Africa, in so-called testimony therapy. In trauma therapy sessions, a written report about relevant findings is drafted by patient and therapist together; it is then put at the client's disposal and thus "bears witness" (Agger \& Jensen, 1990; Cienfuegos \& Monelli, 1983). As concerns the therapeutic effect, this procedure can best be compared with the more complex cognitive-behavioural methods, such as cognitive processing therapy, which integrate exposition, mediation of knowledge, and cognitive restructuring. By working out the document in common, the exposition occurs in carefully measured doses, as is quite essential with victims of torture.

Problems arising from the laws on foreigners weigh heavily on the treatment of refugees and migrants in forensic psychiatry. Again and again, therapists are forced into a double role: to treat the patient, but also to take a position on his or her prognosis and other questions that can have serious practical consequences. And beyond that, accommodation in a forensic psychiatry unit, given its setting and the patient group being treated there, always holds the danger of retraumatisation and makes therapeutic access to the traumatic material of victims of torture and politically persecuted refugees difficult. We therefore prefer carrying out the trauma-specific parts of the treatment separate from the psychotherapeutic process in the forensic ward, and we greatly value the cooperation of our colleagues in the Outpatient Clinic for Refugees in this respect. With their help, it is also easier to integrate the material worked through there into the forensic psychotherapy. 
The assessment showed that according to DSMIV (American Psychiatric Association, 1994) the criteria for a stress disorder were fulfilled:

- Traumatic experiences occurred; most serious among them was the torture in the Algerian prison followed by solitary confinement (criterion $\mathrm{A}$ ).

- The patient suffers several times each week under intrusive thoughts (experiences of torture), and also following discussions in the therapy. Nightmares occur about once a week. Triggered by intrusive thoughts, anxiety, rage, and sadness appear, as well as unspecific body reactions such as weakness and trembling (criterion B).

- The patient avoids discussion of the intrusive thoughts and tries to "push them away." He steers clear of news programmes on television, from fear of seeing pictures from Algeria that could again set off intrusive thoughts (criterion $\mathrm{C}$ ).

- The patient has problems sleeping. He throws inappropriate tantrums and displays exaggerated fright reactions (criterion $\mathrm{D}$, overexcitement symptoms).

- The symptoms first appeared after the torture and have persisted now for 12 years (criterion E).

- The symptoms cause impairments in the areas of relationships and leisure time. Moreover, the forensic internment itself - as a secondary result of drug consumption and overexcitement - can be attributed to the traumatisation (criterion F).

Dissociative and somatic symptoms are not present. The initial drug consumption can be directly attributed to the avoidance of intrusive thoughts and aversive emotions.

The examination in the neuromagnetometer showed an accumulation of focally generated, abnormally slow waves in the frontal and temporal lobes of the brain. Without going into detail, a neuropsychological correlate of the PTSD (frontal finding) and the reported psychotic reaction (temporal finding) shows up here.

In mid-2004, the trauma therapy began parallel to the individual psychotherapy and lasted up to $\mathrm{Mr} A$ 's release; one result is a comprehensive account by the patient of what he had lived through in Algeria and during his flight. During this treatment, the nightmares, flashback experiences, and intrusive thoughts diminished considerably. He was able to take a small apartment outside the clinic and continue his therapy and work inside the clinic. It was clear to everyone, however, that the outlook for his future was very uncertain. Whereas the judicial authorities advocated a professional treatment that promised results and would make his reintegration possible, the authorities responsible for foreigners disapproved of his living permanently close to the clinic and refused to issue him a work permit.

The patient's condition continued to stabilise, so that we could venture a positive prognosis. $\mathrm{He}$ was drug-free, lived to a great extent independently in a steady love relationship, and performed his work regularly and dependably. His release from the special measure term became topical once the positive prognosis had been made. It was only the unclarified questions under the laws on foreigners that were the remaining obstacle to his release!

Here he could make no headway. In the last analysis, the authorities held to their decision not to grant him a work permit until he presented valid identification papers (which on the other side would greatly simplify his deportation) and ordered him back to the city some $250 \mathrm{~km}$ away from whence he came, where he was to be quartered in the facility where he had last dealt in and consumed drugs. But we were able to negotiate a special arrangement for him so that he could live in another facility and in a private room.

\section{No happy ending}

This is the sobering conclusion to an extensive and successful therapy in which aspects of forensic psychiatry and finally also of the judicial system clashed with rulings under the laws governing foreigners. Both the patient and we ourselves felt a great helplessness in the face of these insurmountable hurdles. A resigned attitude on $\mathrm{Mr}$ A's part would have been understandable.

But our patient showed us that he had profited from the treatment. He has remained stable, kept away from crime, manifested his emotions, and is determined to make the best of the situation. At the time of his release, he still hoped that a positive court decision would enable him to work in Germany and to lead a socially well-adjusted life. It is helpful to him that he has not been left alone following the treatment, but that he can make use of counselling and therapeutic services. Here he sees an essential difference from his earlier situation. The trauma therapy and narrating his experiences in Algeria, including critical scrutiny of his own role as a perpetrator, have not only improved the symptoms of his PTSD substantially, but also given back to him a feeling of dignity, self-respect, and efficacy.

Despite the unsatisfying, even counterproductive circumstances at the time of his release, we believe 
that our work was not in vain and that we contributed something to the mastery of a difficult situation that we, in the final analysis, cannot change through psychotherapy. For us, Mr A's treatment is a model for the integration of forensic psychotherapy and trauma therapy for refugees and migrants in the forensic division.

\section{Acknowledgements}

We thank Charles Edward Brooks for the English translation and helpful comments.

\section{References}

Agger, I., \& Jensen, S.B. (1990). Testimony as ritual and evidence in psychotherapy for political refugees. fournal of Traumatic Stress, 3, 115-30.

American Psychiatric Association (1994). Diagnostic and statistical manual of mental disorders (4th ed.). Washington: APA.

Cienfuegos, A., \& Monelli, C. (1983). The testimony of political repression as a therapeutic instrument. American fournal of Orthopsychiatry, 53, 4-51.

Garieballa, S. (2004). Trauma, post-traumatic stress disorder and psychiatric comorbidity in forensic patients. Unpublished dissertation: University of Constance.

Garieballa, S., Schauer, M., Neuner, F., Saleptsi, E., Kluttig, T., Elbert, Th., Hofmann, K., \& Rockstroh, B. (2006). Traumatic events, PTSD, and psychiatric comorbidity in forensic patients - assessed by questionnaires and diagnostic interview. Clinical Practice and Epidemiology in Mental Health, 2, 1-7.

Hausner, H., Wittmann, M., \& Cording, C. (2006). Forensische Psychiatrie im Wandel [Forensic psychiatry in transformation]. Krankenhauspsychiatrie, 17, 68-73.

Hoffmann, K. (2006). Migranten als Patienten im Maßregelvollzug [Migrants as patients with special measure sentences]. Der Nervenarzt, 77, 50-7.

Hoffmann, K., Kluttig, T., \& Ross, T. (in press). Work immigrants as patients in German forensic psychiatry and psychotherapy.

Kluttig, T. (2003). Täter oder Opfer? Zur Bedeutung posttraumatischer Belastungsstörungen für die forensische Psychotherapie [Perpetrators or victims? On the meaning of post-traumatic stress disorder for forensic psychotherapy]. Forensische Psychiatrie und Psychotherapie, 10(3), 49-69.
Koch, E., Hartkamp, N., \& Schouler-Ocak, M. (2007). Patienten mit Migrationshintergrund - eine Umfrage zur Inanspruchnahme stationärer Versorgung [Patients with a migration background - an investigation of the use of in-patient care]. Psychiatrische Praxis, 34, 361-2.

Schauer, M., Kluttig, T., Elbert, T., Junghöfer, M., Neuner, F., Hoffmann, K., \& Rockstroh, B. (2002). Trauma and delinquency: Psychophysiological evidence for the dysregulation of affect in traumatized forensic patients. Psychophysiology, 39, S75.

Soen, D., Scehory, M., \& Ben-David, S. (Eds) (forth coming). Work immigrants and social problems: an international perspective.

\section{Authors}

Tilman Kluttig is a clinical psychologist and psychotherapist. He is senior clinical psychologist in the Department for Forensic Psychotherapy and Pyschiatry in Reichenau Centre for Psychiatry, Germany. He trained as a psychodrama therapist, family therapist, cognitive-behavioral therapist and in psychoanalytical psychotherapy for patients with psychotic disorders. Since 2002 he is a board member of the International Association for Forensic Psychotherapy.

Michael Odenwald, PhD, Dipl. Psych., has studied psychology in Würzburg, Lisbon and Konstanz and has received training in cognitive and behavioural therapy. His research focuses on PTSD, substance abuse and psychosis in post-conflict regions and among refugees and migrants in western countries. $\mathrm{He}$ is also involved in clinical neurobiological research. He currently works in a clinical research setting at the University of Konstanz, Germany, and leads a joint research project on substance use among migrants with the Reichenau Centre for Psychiatry, Germany.

Werner Hartmann is a psychiatrist and psychotherapist in the Department for Forensic Psychotherapy and Psychiatry in Reichenau Centre for Psychiatry, Germany. 